\title{
Massive hepatic resection for the carcinoid syndrome
}

\author{
R. ZEEGEN, R. ROTHWELL-JACKSON, AND M. SANDLER \\ From St Bartholomew's Hospital, and the Bernhard Baron Memorial Research Laboratories \\ and Institute of Obstetrics and Gynaecology, Queen Charlotte's Maternity Hospital, London
}

SUMMARY Removal of the right lobe of the liver which was occupied largely by metastases, together with resection of ileal primary tumours, brought about complete remission of symptoms and signs in a 43-year-old man with a six-year history of the carcinoid syndrome. Investigations should be orientated toward surgery. When practicable, radical surgery of the type described here appears to offer the best hope of alleviating the distressing clinical features of the condition.

The carcinoid syndrome has given rise to a literature disproportionate to its rarity (for review, see Kähler and Heilmeyer, 1961). Much of the interest it has aroused lies in the possible role of certain potent pharmacologically active agents deriving from tumour tissue in the pathogenesis of the usual physical signs of the condition (Sandler, 1968; Sandler, Karim, and Williams, 1968). Although an oversimplification, it is probably reasonably true to say that the severity of the symptoms, notably flushing and diarrhoea, likely to stem from the humoral effect of these substances is roughly proportional to the mass of secreting tumour tissue.

The greater mass of tumour metastases is usually situated in the liver and may be extremely slow growing. Affected subjects may consequently survive for many years, albeit with disabling clinical features of the syndrome. It is therefore important to afford some relief to the patient afflicted with these distressing symptoms. At present, medical treatment is of limited value. Removal of as much secreting tissue as possible is the most rational approach and palliative resection of hepatic metastases has been carried out in a small number of cases with encouraging results (Stanford, Davis, Gunter, and Hobart, 1958; Wilson and Butterick, 1959; Crile, 1959; Williams and Azzopardi, 1960; Mosenthal, 1963; Shorb and McCune, 1964; Chandler and Foster, 1965; Adson and Jones, 1966; Ludin, Fahrländer, and Renggli, 1966; Bersohn and Bleloch, 1967; Gardner, Dollinger, Silen, Back, and O'Reilly, 1967; Leahy and Moloney, 1967). We now report a further case, where there was complete relief of symptoms following resection of primary lesions in the ileum and massive hepatic metastases. Furthermore, the patient has been asymptomatic since operation and levels of 5-hydroxyindoleacetic acid (5-HIAA) in the urine have remained normal up to 18 months postoperatively.

The mass of liver tissue successfully resected in this case is the largest recorded in the world literature. The dramatic relief afforded to the patient has more than justified this extensive surgical procedure.

\section{CASE REPORT}

Mr W. G., aged 43, had his first symptom of attacks of diarrhoea in 1961. The stool contained copious quantities of mucus but no blood. One year later he was found to have an enlarged liver and was admitted to hospital. All investigations, including sigmoidoscopy, barium studies, and liver function tests, were negative. He underwent laparotomy (25 October 1962) and was found to have two tumours in the right lobe of the liver, one the size of a cricket ball and the other three-quarters of an inch in diameter. No primary lesion was found. Almost a year later he began to complain of troublesome facial flushing and urinary 5-HIAA levels were found to be elevated. Readmission to hospital with a view to further laparotomy was declined by the patient. In May 1964, he was seen at another hospital complaining of diarrhoea, pain in the upper right quadrant of the abdomen, and distressing attacks of flushing of the face and upper trunk brought on by eating, drinking beer, and physical exertion. He was started on methysergide, $1 \mathrm{mg}$ tds, with some improvement in the diarrhoea. He was later transferred to the care of Dr A. M. Dawson at St Bartholomew's Hospital and subsequently admitted in November 1955. The most distressing symptom at this time was the intense flushing. It was noted, however, that this and the diarrhoea were to some extent related to stress, for several months before admission he had spent a relaxing holiday in Spain with complete relief of symptoms. An attempt was made to bring about pharmacological control of the flushing and it was found that propranolol in a dose of $10 \mathrm{mg}$ qds aborted a noradrenaline-induced flush and markedly reduced the frequency of spontaneous flushes. 
Gradually the beneficial effect of propranolol diminished. Although his general health remained good he was passing six to eight loose motions daily despite methysergide treatment and was flushing some 10 to 20 times a day. In view of the relatively slow progression of the disease and the failure of medical control, the patient was readmitted in April 1967 for reassessment with a view to surgery.

On examination he had a permanently reddened face with dilated superficial vessels over the nose, cheeks, and forehead. There was a characteristic violaceous hue over the malar area. The skin elsewhere was normal. There was no evidence of congestive cardiac failure or valvular heart lesion. His pulse and blood pressure were normal. There was massive hepatomegaly, the lower border of the liver reaching almost to the right iliac fossa. Its surface was hard and irregular and it was not tender. There were no other abdominal masses. During examination there were repeated attacks of flushing involving the face and the whole of the upper trunk. These were not related to palpation of the tumour.

INVESTIGATIONS These were made in April 1967 and the following results were obtained: haemoglobin $12.3 \mathrm{~g} / 100$ $\mathrm{ml}(84 \%)$; the blood film was normal; the ESR was $15 \mathrm{~mm}$ in one hour (Westergren); the serum bilirubin value was $0.3 \mathrm{mg} / 100 \mathrm{ml}$; the serum alkaline phosphatase, 11-KA units $/ 100 \mathrm{ml}$; SGOT, 22 units $/ 1$; the serum albumin level $4.8 \mathrm{~g} / 100 \mathrm{ml}$; xylose excretion test $(25 \mathrm{~g}$ dose) $4 \mathrm{~g}$ excreted in five hours; three-day faecal fat, $3.4 \mathrm{~g}$ excreted daily; the Schilling test (part two) $28.4 \%$ of dose excreted in 24 hours; the urine 5-HIAA (Udenfriend, Titus, and Weissbach, 1955) was between 48 and $238 \mathrm{mg} / 24$ hours (see Table), (the normal adult range is 2 to $8 \mathrm{mg}$ per 24 hours); urine-indole chromatography (Jepson, 1955), apart from a large 5-HIAA spot, no other abnormality was observed. The pattern was character-

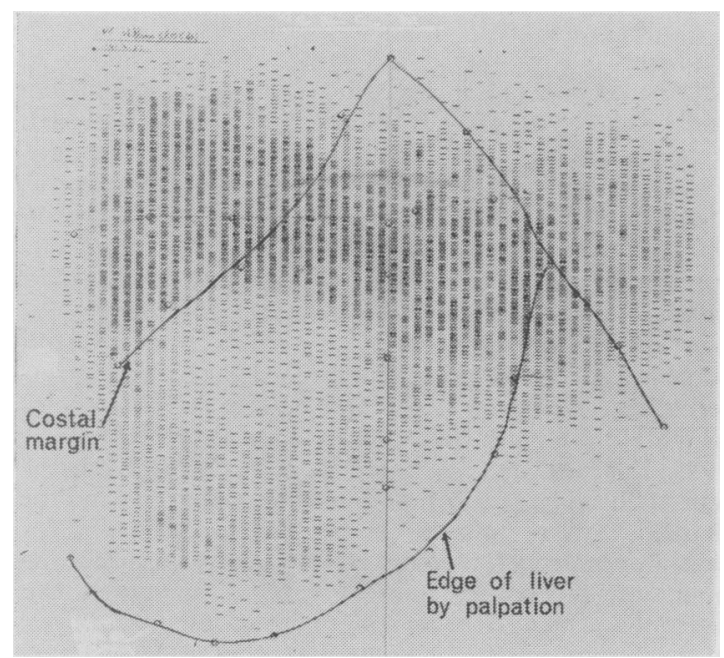

FIG. 1a. Radio-gold liver scan showing large filling defect in the right lobe. istic of midgut carcinoid. Chest radiographs and ECG were normal. A liver scan using radioactive colloidal gold showed a single large filling defect in the right lobe with a reasonable mass of apparently normal liver on the left (Fig. 1a). A hepatic arteriogram showed gross enlargement of the hepatic artery and its main branches; the right lobe of the liver was almost entirely replaced by vascular tumour deposits, but the left appeared to be free from tumour (Figs. 2a and b).

These findings suggested that a bold surgical approach might achieve removal of the hepatic metastases and still leave sufficient normal liver to ensure the patient's survival. The serious nature of the proposed surgical procedure was explained to him and he readily agreed to undertake this risk if there were a reasonable chance of losing his distressing symptoms.

The operation was carried out (27 June 1967) by $\mathrm{Mr}$ A. H. Hunt. Anaesthesia was uneventful. The previous upper midline incision was reopened and extended upwards to the xiphisternum and laterally along the lower border of the liver as a low Kocher incision. Three large secondary growths were found in the right lobe of the liver, one of which extended to the left of the falciform ligament. The rest of the left lobe of the liver appeared to be normal. Palpation of the bowel revealed a primary tumour in the ileum, three and a half feet from the ileocaecal junction, with a single enlarged lymph gland in the adjacent mesentery.

A portal venogram and an operative cholangiogram were obtained to show where the portal vein and the common hepatic duct divided and while these films were being developed the small bowel lesion was resected. A further extension of the incision was then made upwards and laterally along the ninth interspace. The pleura was not opened. The structures in the porta hepatis were then defined, with ligation of the cystic duct, right hepatic artery, right hepatic duct, and the right branch of the

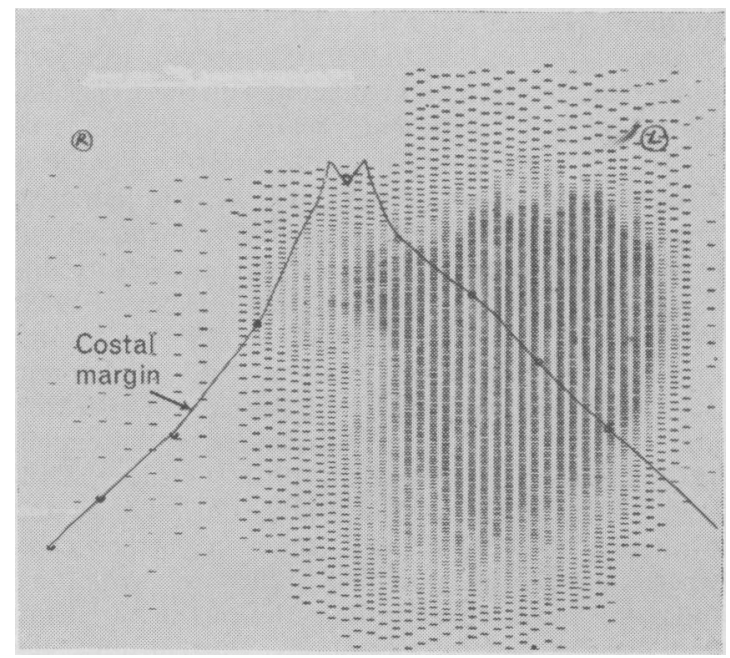

FIG. 1b. Technetium liver scan seven months postoperatively showing little regeneration of the right lobe. 


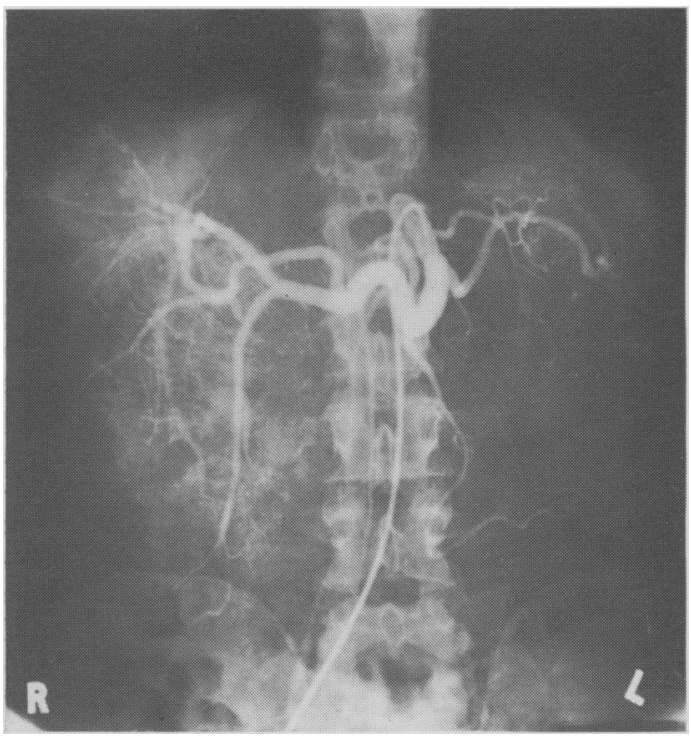

FIG. 2a. Hepatic arteriogram showing tumour circulation in the right lobe.

portal vein. The patient was then rotated to the left, and the right triangular and coronary ligaments were divided, and the dissection carried up along the inferior vena cava with a division of hepatic venules and two right hepatic veins. The metastasis which had previously been noted to extend to the left of the falciform ligament was now seen

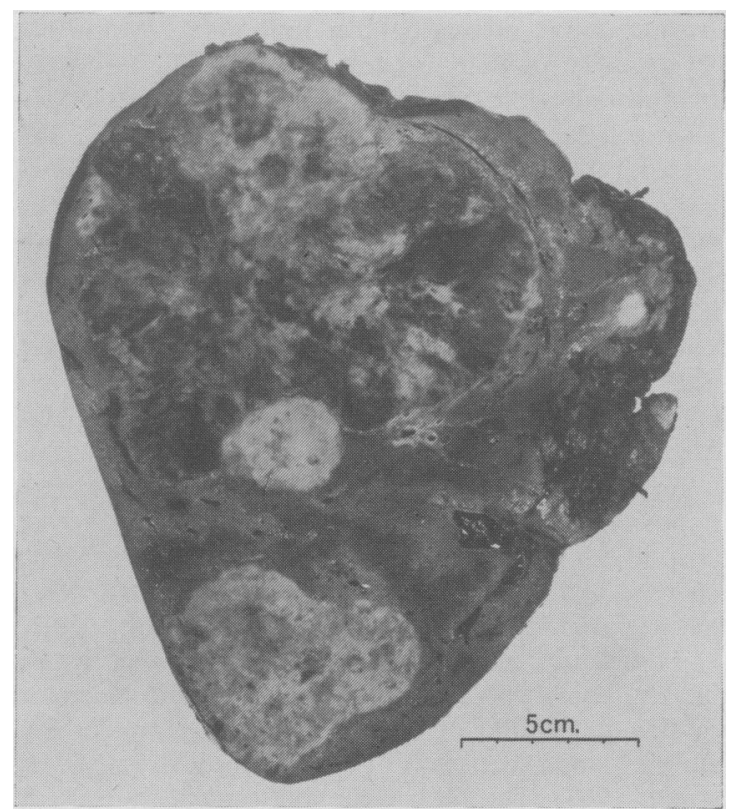

FIG. 3. Resected specimen showing huge carcinoid deposits in the right lobe of the liver.

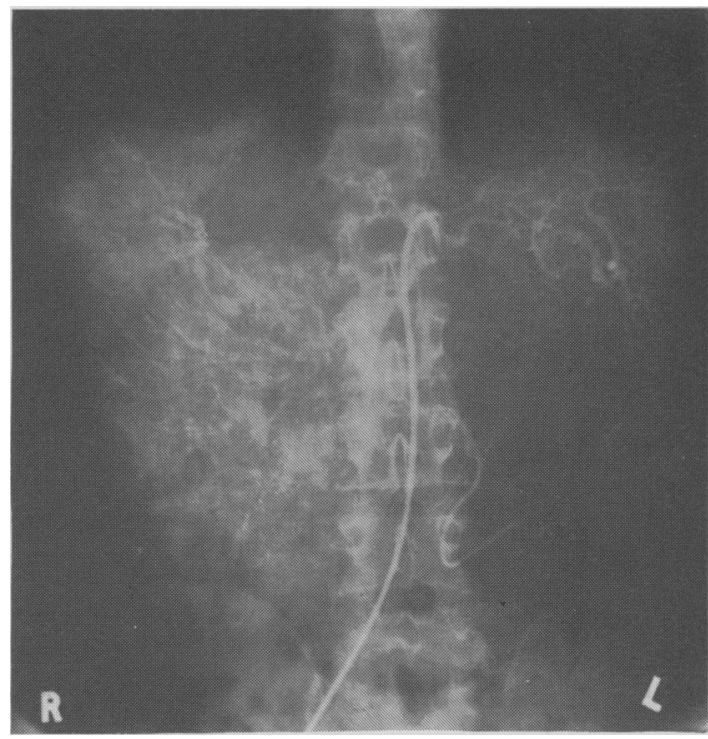

FIG. 2b. Hepatogram phase showing most of the right lobe replaced by tumour.

to extend beyond the line of demarcation of the ischaemic right lobe of the liver. Resection was therefore carried out to the left of the line of demarcation to ensure complete excision of tumour tissue and the division of liver tissue was continued obliquely downwards towards the porta hepatis. The liver substance was divided by blunt dissection, vessels and ducts being clamped and divided and then ligated or oversewn. Haemorrhage was no more than moderate and was easily controlled. A Penrose drain was inserted down to the bare area of the liver, which was loosely covered with haemostatic gauze and omentum. The abdomen was closed with catgut to peritoneum and interrupted steel wire to muscle. The weight of tissue resected from the liver was 1,780 g (Fig. 3). Five pints of blood and $50 \mathrm{~g}$ albumin were transfused during operation and the immediate postoperative period.

Postoperative progress was remarkably uneventful and at no time did he show any signs of hepatic insufficiency. Intravenous fluids were discontinued on the fourth day, the abdominal drain was removed on the seventh, he was fully mobile by the eighth, and sutures were removed on the eleventh day. He was allowed home for week-end leave five weeks after operation and was discharged from hospital two weeks later.

The facial discoloration started to fade the day after operation and he had no further attacks of flushing or diarrhoea thereafter. The dilated venules on the face regressed considerably during his time in hospital and urinary 5-HIAA levels dropped dramatically to below normal levels (Table). Repeat liver scans showed very little in the way of regeneration of the right lobe (Fig. 1b).

His subsequent progress (December 1968) has been equally satisfactory and there has been no recurrence of symptoms. Urinary 5-HIAA values have gradually crept up to the upper limit of normal (Table); although 
TABLE

PRE- AND POSTOPERATIVE LEVELS OF URINARY 5-HIAA ${ }^{1}$

\begin{tabular}{|c|c|c|c|}
\hline \multicolumn{2}{|c|}{ Preoperative } & \multicolumn{2}{|c|}{ Postoperative } \\
\hline Date ${ }^{2}$ & $\begin{array}{l}\text { Urinary } 5-H I A A \\
\text { (mg per } 24 \mathrm{hr})\end{array}$ & Date $^{2}$ & $\begin{array}{l}\text { Urinary 5-HIAA } \\
\text { (mg per } 24 \mathrm{hr} \text { ) }\end{array}$ \\
\hline $\begin{array}{l}14.6 .67 \\
15.6 .67 \\
16.6 .67 \\
17.6 .67 \\
18.6 .67 \\
19.6 .67 \\
20.6 .67 \\
26.6 .67\end{array}$ & $\begin{array}{r}216 \\
191 \\
230 \\
48 \\
106 \\
60 \\
72 \\
62\end{array}$ & $\begin{array}{l}26.7 .67 \\
27.7 .67 \\
28.7 .67 \\
29.7 .67 \\
31.7 .67 \\
1.12 .67 \\
2.12 .67 \\
8.3 .68 \\
10.3 .68 \\
13.3 .68 \\
14.3 .68 \\
30.9 .68 \\
1.10 .68 \\
2.10 .68 \\
3.10 .68 \\
5.12 .68 \\
6.12 .68\end{array}$ & $\begin{array}{l}0.4 \\
0.4 \\
0.4 \\
0.7 \\
0.8 \\
2.2 \\
5.4 \\
6.3 \\
3.0 \\
1.7 \\
0.6 \\
8.0 \\
7.9 \\
7.1 \\
9.7 \\
7.4 \\
8.0\end{array}$ \\
\hline
\end{tabular}

${ }^{1}$ Normal adult range 2 to $8 \mathrm{mg} / 24 \mathrm{hr}$.

'Estimations up to and including that of 14.3 .68 were carried out by the method of Udenfriend et al (1955). Subsequent analyses were performed by the method of Contractor (1966).

this observation is complicated by a change in analytical method, it is thought that the findings are not incompatible with the presence of a small amount of secreting tumour tissue.

PATHOLOGICAL REPORT The resected liver weighed $1,780 \mathrm{~g}$ and measured $21 \times 18 \times 10 \mathrm{~cm}$. Through its substance were several large, firm, roughly spherical tumours of up to $13 \mathrm{~cm}$ diameter. The largest deposit had undergone central degeneration and haemorrhage. Histology showed poorly differentiated carcinoid.

The resected loop of small bowel was $18 \mathrm{~cm}$ long and contained three primary tumour nodules of $1 \cdot 0,0 \cdot 8$, and 0.5 cm diameter.

Histological section showed circumscribed nodules of well differentiated carcinoid confined to the mucosa and submucosa. Section of the lymph node in the mesentery showed poorly differentiated tumour, the histological appearance being more like that of the liver deposits than of the bowel primaries.

\section{DISCUSSION}

A bewildering variety of medical approaches (eg, Ureles, Murray, and Wolf, 1962; Vroom, Brown, Dempsey, and Hill, 1962) has been used to treat the tumour itself, such as irradiation (eg, Krikler, Lackner, and Sealy, 1958; Elliott, Grace, and Gibson, $1962)$ and cytotoxic drugs (eg, Kirkpatrick, 1959; Gailitis, 1960) or those to stem the synthesis (eg, Sjoerdsma, Oates, Zaltzman, and Udenfriend, 1960; Engelman, Lovenberg, and Sjoerdsma, 1967) or action (Dubach and Gsell, 1962) of 5-hydroxytryptamine or of kallikrein (eg, Kinloch, Webb, Eccleston, and Zeitlin, 1965; Grahame-Smith, 1965;
Gardner et al, 1967) which gives rise to the flushpromoting substance, bradykinin (for review, see Oates and Butler, 1967). Although every gradation of improvement has been hopefully documented, there appears to be great variation in patient's responses. The general impression, however, is that medical treatment is less than satisfactory, although the beneficial effect of propranolol (Mason and Melmon, 1966; Morelli, Brown, and Melmon, 1967; Ludwig, Cushard, Bartuska, Franco, and Chaykin, 1968) on the flush of the present patient should be noted.

Surgery remains the only means of effective attack on the tumour and its metastases, and presumably of preventing the onset of the irreversible (Thorson, Hanson, Pernow, Söderström, Waldenström, Winblad, and Wulff, 1958) carcinoid heart disease; the present case demonstrates that massive resection may cause the clinical features of the carcinoid syndrome to disappear completely. An additional hazard of surgery for carcinoid disease, the development of anaesthetic problems which tend to be resistant to treatment (Leahy and Moloney, 1967), must be taken into account when assessing the risks of this type of radical operation. This aspect has been reviewed by Jones (1959).

The remarkably slow growing nature of the carcinoid tumour lends itself to surgical extirpation (Ogilvie, 1953). Even when metastases are widespread in the liver and not localized, as in this case, resection of the bulk of the tumour mass may substantially alleviate the patient's symptoms. The patient of Bersohn and Bleloch (1967) and our own were both fortunate in having secondary lesions localized largely to a single lobe of the liver, thus offering the prospect of cure and not merely of palliation. The other reported cases all had metastases in both lobes. Even so, resection gave immediate symptomatic relief, accompanied by a dramatic fall in urinary 5-HIAA output. The first such case involving massive hepatic surgery, reported by Wilson and Butterick (1959) and also recorded elsewhere (Wilson, 1959; Wilson and Storer, 1959; Wilson, Storer, and Star, 1963; Wilson, 1964 and 1967), had a resection of $1,182 \mathrm{~g}$ of liver containing tumour deposits, and a second resection of $175 \mathrm{~g}$ was carried out four and a half years later with relief of recurrent symptoms (Wilson et al, 1963). In 1967, he was reported to be still alive (Wilson, 1967).

Techniques of liver resection are now well established. The successful outcome of hepatic resection of the magnitude of right lobectomy is made possible by four factors (Guynn, Reynolds, and Overstreet, 1963). The first is the anatomical division of the liver into right and left lobes, and our recent better understanding of the anatomy of the hepatic 
veins which follow a different (intersegmental) course. Secondly, maintenance of circulating blood volume is essential in an operation of this magnitudeand can only be assured by the careful monitoring of central venous pressure. Thirdly, resection of the major part of the liver is only made feasible by a reserve of physiological function in the remaining liver tissue. The fourth important factor favouring recovery of the patient after massive hepatic resection is the ability of the liver to regenerate. In animals, virtually complete regeneration occurs quite rapidly after massive resection (Bucher, 1967), and, while the evidence in man is obviously not so complete, the same appears to be true although at a slower pace (Pack, Islami, Hubbard, and Brasfield, 1962; McDermott, Greenberger, Isselbacher, and Weber, 1963).

Guynn et al (1963) recommend a high-protein, high-carbohydrate diet with oral or parenteral glucose supplements for several days before surgery in an attempt to prevent postoperative liver failure. Postoperative albumin infusions would seem to be a wise precaution in view of the reported frequency of hypoalbuminaemia after partial hepatic resection (Pack and Molander, 1960; Bersohn and Bleloch, 1967).

A further surgical problem in the treatment of the carcinoid syndrome is that of resecting the primary lesion. Most commonly, this is found in the terminal ileum but may sometimes be so small as to escape careful search. In the present case and case 1 of Wilson and Butterick (1959), no primary lesion was found at the first laparotomy and it was not until a second operation that a length of ileum containing several tumours was found. Such multiplicity of origin is not uncommon (MacDonald, 1956) and one case reported by Shorb and McCune (1964) had $90 \mathrm{~cm}$ of ileum resected containing no less than 96 separate tumours. Even when laparotomy discloses an obvious primary lesion, the finding should not deter the surgeon from making a most careful search for other carcinoid tumours throughout the alimentary tract.

After the removal of tumour tissue in the patient described here, urinary 5-HIAA output fell to less than normal values and remained there for over a month after operation. The patient was not taking any drug which might have interfered (Mustala, 1965) with the method of assay employed. As the time interval would exclude a simple feedback effect such as that of 5-hydroxytryptamine on 5-hydroxytryptophan decarboxylase (Contractor and Jeacock, 1967), some suppressive action of the tumour on the enterochromaffin cell system, which probably elaborates a major proportion of the 5-hydroxyindoles produced in the body (Hagen and Cohen, 1966), must probably be invoked.
Another unexplained feature concerns the wide fluctuation observed in preoperative 5-HIAA values. Although this phenomenon has been noted by other authors (eg, Hanson and Serin, 1955), no satisfactory explanation for it has yet been proposed. It may reflect some characteristic of the patient himself rather than of the tumour, for a similar tendency to widely fluctuating values at the new lower level was evident in the later postoperative urine samples.

This case demonstrates the feasibility of operative treatment even though six years had elapsed since the onset of the initial symptoms and three years of disabling ones. Improved techniques of hepatic resection and the slow growing nature of the tumour militate for success in this situation. Even with palliative resection of the bulk of liver containing tumour, symptoms may be considerably diminished or even disappear completely. Thus it is essential to adopt an aggressive policy towards patients with the carcinoid syndrome; they should be investigated, and established cases re-investigated, with the possibility of hepatic lobectomy in mind.

We should like to thank $\operatorname{Dr} \mathrm{A}$. M. Dawson and $\mathrm{Mr}$ Alan Hunt for permission to publish details of this case, and the Department of Medical Photography of St Bartholomew's Hospital for the illustrations.

\section{REFERENCES}

Adson, M. A., and Jones, R. R. (1966). Hepatic lobectomy. Arch.Surg., 92, 631-635.

Bersohn, I., and Bleloch, J. A. (1967). Right hemi-hepatectomy in secondary carcinoid of the liver: clinical course and liverfunction tests. $S$. Afr. med. J., 41, 271-274.

Bucher, N. L. R. (1967). Experimental aspects of hepatic regeneration. New Engl. J. Med., 277, 686-696.

Chandler, J. J., and Foster, J. H. (1965). Malignant carcinoid syndrome treated by resection of hepatic metastases. Amer. J. Surg., 109, 221-222.

Contractor, S. F. (1966). A rapid quantitative method for the estimation of 5-hydroxyindoleacetic acid in human urine. Biochem. Pharmacol., 15, 1701-1706.

controlling the biosynthesis of 5-hydroxytryptamine. Biochem. Pharmacol., 16, 1981-1987.

Crile, G., Jr (1959). In discussion following paper by Quattelbaum, J. K., and Quattelbaum, J. K., Jr. Technic of hepatic lobectomy. Ann Surg., 149, 651.

Dubach, U. C., and Gsell, O. R. (1962). Carcinoid syndrome: alleviation of diarrhoea and flushing with 'Deseril' and Ro 5-1025. Brit. med. J., 1, 1390-1391.

Elliott, G. B., Grace, D. A., and Gibson, H. E. (1962). The serotonin syndrome in carcinoidosis. Canad. J. Surg., 5, 70-75.

Engelman, K., Lovenberg, W., and Sjoerdsma, A. (1967). Inhibition of serotonin synthesis by para-chlorophenylalanine in patients with the carcinoid syndrome. New Engl. J. Med., 277, 11031108.

Gailitis, R. J. (1966). The malignant carcinoid syndrome: report of 5 cases. Amer. J. dig. Dis., 11, 630-647.

Gardner, B., Dollinger, M. Silen, W. Back, N., and O'Reilly, S. (1967). Studies of the carcinoid syndrome: its relationship to serotonin, bradykinin, and histamine. Surgery, 61, 846-852.

Grahame-Smith, D. G. (1965). Carcinoid syndrome. Proc. roy. Soc. Med., 58, 701-702.

Guynn, V. L., Reynolds, J. T., and Overstreet, R. J. (1963). Right hepatic lobectomy. Technical problems and patient management. Surg. Clin. N. Amer., 43, 63-77. 
Hagen, P. B., and Cohen, L. H. (1966). Biosynthesis of indolealkylamines. Physiological release and transport of 5-hydroxytryptamine. In Handbuch der experimentellen Pharmakologie, vol. 19, edited by V. Erspamer, pp. 182-211, Springer, Berlin.

Hanson, A., and Serin, F. (1955). Determination of 5-hydroxy-indoleacetic acid in urine and its excretion in patients with malignant carcinoids. Lancet, 2, 1359-1361.

Jepson, J. B. (1955). Paper chromatography of urinary indoles. Ibid, 2, 1009-1011.

Jones, W. P. G. (1959). Serotonin and the carcinoid syndrome. Canad. Anaesth. Soc.J., 6, 130-140.

Kähler, H. J., and Heilmeyer, L. (1961). Klinik und Pathophysiologie des Karzinoids und Karzinoidsyndroms unter besonderer Berucksichtigung der Pharmakologie des 5-Hydroxytryptamins. Ergebn. inn. Med. Kinderheilk., 16, 292-559.

Kinloch, J. D., Webb, J. N., Eccleston, D., and Zeitlin, J. (1965). Carcinoid syndrome associated with oat-cell carcinoma of bronchus. Brit. med. J., 1, 1533-1535.

Kirkpatrick, C. H. (1959). Malignant carcinoid tumours. J. Kansas med. Soc., 60, 551-555.

Krikler, D. M., Lackner, H., and Sealy, R. (1958). Malignant argentaffinoma and the carcinoid syndrome. S. Afr. med. J., 32, 514 520 .

Leahy, J., and Moloney, M. A. (1967). The carcinoid syndrome. Irish J. med. Sci., 269-276.

Ludin, H., Fahrländer, H. J., and Renggli, I. (1966). Zur Darstellung von Karzinoid-Lebermetastasen mittels visceraler Arteriographie. Schweiz. med. Wschr., 96, 1642-1648.

Ludwig, G. D., Cushard, W., Bartuska, D., Franco, R., and Chaykin, L. (1968). Effects of beta-adrenergic blockade in the carcinoid syndrome. (Abstract.) Ann. int. Med., 68, 1188.

McDermott, W. V., Jr, Greenberger, N. J., Isselbacher, K. J., and Weber, A. L. (1963). Major hepatic resection: diagnostic techniques and metabolic problems. Surgery, 54, 56-66.

MacDonald, R. A. (1956). A study of 356 carcinoids of the gastrointestinal tract. Report of four new cases of the carcinoid syndrome. Amer. J. Med., 21, 867-878.

Mason, D. T and Melmon, K. L. (1966). New understanding of the mechanism of the carcinoid flush. Ann. int. Med., 65, 1334-1339.

Morelli, H., Brown, E., and Melmon, K. L. (1967). Two possible mechanisms for effective therapy of the carcinoid flush. (Abstract.) Clin. Res., 15, 95.

Mosenthal, W. T. (1963). Resection of massive liver metastases in the malignant carcinoid syndrome. Review and report of a case. Surg. Clin. N. Amer., 43, 1253-1262.

Mustala, O. (1965). Specificity of the nitrosonaphthol reaction in the determination of urinary 5-hydroxyindoleacetic acid. Ann. Med. exp. B. Fenn., 43, Suppl. 8, pp. 1-48.

Oates, J. A., and Butler, T. C. (1967). Pharmacologic and endocrine aspects of carcinoid syndrome. Advanc. Pharmacol.. 5, 109-128.

Ogilvie, H. (1953). Partial hepatectomy. Observations on an illustrative case. Brit. med. J., 2, 1136-1138.
Pack, G. T., Islami, A. H., Hubbard, J. C., and Brasfield, R. D. (1962). Regeneration of human liver after major hepatectomy. Surgery, 52, 617-623.

- , and Molander, D. W. (1960). Metabolism before and after hepatic lobectomy for cancer. Arch. Surg., 80, 685-692.

Sandler, M. (1968). The role of 5-hydroxyindoles in the carcinoid syndrome. Advanc. Pharmacol., 6B, 127-142.

—, Karim, S. M. M., and Williams, E. D. (1968). Prostaglandins in amine-peptide-secreting tumors. Lancet, 2, 1053-1055.

Shorb, P. E., Jr, and McCune, W. S. (1964). Carcinoid tumors of the gastrointestinal tract. An analysis of seventy cases. Amer. J. Surg., 107, 329-336.

Sjoerdsma, A., Oates, J. A., Zaltzman, P., and Udenfriend, S. (1960). Serotonin synthesis in carcinoid patients: its inhibition by a-methyl-DOPA, with measurement of associated increases in urinary 5-hydroxytryptophan. New Engl. J. Med., 263, 585-588.

Stanford, W. R., Davis, J. E., Gunter, J. U., and Hobart, S. G., Jr (1958). Bronchial adenoma (carcinoid type) with solitary metastasis and associated functioning carcinoid syndrome. Southern med. J., 51, 449-454.

Thorson, $\AA$., Hanson, A., Pernow, B., Söderström, N., Waldenström, J., Winblad, S., and Wulff, H. B. (1958). Carcinoid tumour within an ovarian teratoma in a patient with the carcinoid syndrome (carcinoidosis). Acta med. scand., 161, 495-505.

Udenfriend, S., Titus, E., and Weissbach, H. (1955). The identification of 5-hydroxy-3-indoleacetic acid in normal urine and a method for its assay. J. biol. Chem., 216, 499-505.

Ureles, A. L., Murray, M., and Wolf, R. (1962). Results of pharmacologic treatment in the malignant carcinoid syndrome. New Engl. J. Med., 267, 435-438.

Vroom, F. Q., Brown, R. E Dempsey, H and Hill, S. R., Jr (1962). Studies on several possible antiserotonin compounds in a patient with the functioning carcinoid syndrome. Ann. intern. Med., 56, 941-945.

Williams, E. D., and Azzopardi, J. G. (1960). Tumours of the lung and the carcinoid syndrome. Thorax, 15, 30-36.

Wilson, H. (1959). The malignant carcinoid syndrome: massive liver resection for symptomatic relief. Amer. Surgeon, 25, 567-570.

- (1964). In discussion following paper by Shorb, P. E., Jr, and McCune, W. S. Carcinoid tumors of the gastrointestinal tract. An analysis of seventy cases. Amer. J. Surg., 107, 335. (1967). In discussion to paper by Brindley, G. V. Jr, and Bonnet, J. D. Bronchial adenoma and the carcinoid syndrome, Ann. Surg., 165, 679.

_ trol of severe vasomotor reactions secondary to malignant carcinoid. Ann. Surg., 149, 641-647.

—, and Storer, E. H. (1959). Malignant carcinoid syndrome. Arch. Surg., 79, 917-919.

- and Star, F. J. (1968) Carcinoid tumors. A study of seventy-eight cases. Amer. J. Surg., 105, 35-39 